ORIGINAL ARTICLE

\title{
Bacteria Pattern, Results of Antibiotic Sensitivity Test, and Complications of Deep Neck Abscess Patients in Dr. Soetomo General Hospital
}

\author{
Syaiful Rijal $^{1^{*}}$, Achmad Chusnu Romdhoni ${ }^{1}$ \\ ${ }^{1}$ Department of Otorhinolaryngology - Head and Neck Surgery, Faculty of Medicine, Universitas Airlangga - Dr. Soetomo \\ General Hospital, Surabaya, Indonesia
}

\author{
A R T I C L E I N F O \\ Article history: \\ Received 25 September 2018 \\ Received in revised form 24 \\ October 2018 \\ Accepted 1 November 2018 \\ Available online 30 November \\ 2018 \\ Keywords: \\ Deep Neck Abscess, \\ Antibiotic Sensitivity Test. \\ *) Corresponding author: \\ rijalsyaifu101@gmail.com
}

\begin{abstract}
A B S T R A C T
Introduction: Deep Neck Abscess is the accumulation of pus inside the potential space between the deep neck fasciae. The incidence has decreased dramatically since the antibiotic era. Empirical antibiotics are administered before the sensitivity test results out, so it is important to know the map of bacteria and its resistance.

Methods: This study was conducted retrospectively using medical records of patients with deep neck abscess in Dr. Soetomo General Hospital Surabaya during January 2014December 2017. Data recorded included gender, age, location, results of bacteria culture examination, antibiotic sensitivity test, and complications that occurred. Data is processed descriptively.

Results: Of the 162 patients, $102(62.96 \%)$ were males, followed by 60 females $(37.04 \%)$. The 46-60 years old group has the largest percentage (33.95\%). Whereas the most common location of abscess was in the submandibular (42.59\%). Pus culture test, most bacteria is Klebsiella pneumonia (13.04\%). While the sensitivity test shows that meropenem has the highest sensitivity number (73.58). Most complications were sepsis, in 48 patients $(29.63 \%)$.

Conclusion: Klebsiella pneumonia, Staphylococcus aureus, and Streptococcus anginosus are the most common etiologies in deep neck abscess. Meropenem, cefoperazonesulbactam, and oxacillin are the most sensitive antibiotics.
\end{abstract}

\section{Introduction}

Deep neck abscess is the accumulation of pus in the potential space between the deep neck fasciae. This pile of pus occurs as a result of an expansion of various inflammation such as dental infections, pharynx, tonsils, paranasal sinuses, and ears or due to trauma. Symptoms and clinical signs include pain and swelling in the affected neck space. Anatomically, the deep neck potential space is a very complex area. In order to properly perform treatment, knowledge on anatomy of the deep cervical potential space is needed. ${ }^{1}$

The incidence of deep neck abscess has dropped dramatically since the antibiotic era. At present, the exact number of this cases in various major hospitals in Indonesia still unknown. Before the antibiotic era, 70\% of deep neck infections originated from the spread of infections in the pharynx and tonsils to the parapharynx. At present neck infections in children are more often from tonsils. Whereas adults are due to dental infections and diabetes mellitus. Bacteria that cause abscess usually consist of a mixture of aerobic, anaerobic, and facultative anaerobes (polymicrobials). In Spain obtained the results of abscess culture with pathogenic bacteria from the oral cavity and associated with odontogenic disorders (43.80\%), not associated with odontogenic disorders $(21.10 \%)$, bacteria not found in the oral cavity $(34.20 \%))^{2,3}$

The abscess treatment including optimal abscess drainage, bacteria culture from pus, and antibiotic sensitivity test. The results of this examination require a 
long time, so it needs antibiotics based on empirical data. Some researchers report the effectiveness of combination broad-spectrum antibiotics (eg. ceftriaxone-clindamycin and ceftriaxone-metronidazole) with a high yield around $70 \% .^{4,5}$

Currently, there are no wider data and larger number from the entire world in Indonesia considering deep neck abscess. This study is aimed to report the location, etiology, bacteria culture, and sensitivity tests results on patients at Dr. Soetomo General Hospital.

\section{Methods}

This study was conducted retrospectively using secondary data derived from medical records of patients with deep neck abscess in the ENT Inpatient Room Dr. Soetomo General Hospital Surabaya from January 2014 December 2017. Data obtained included gender, age, location, bacteria culture examination results, antibiotic sensitivity tests results, and complications that occurred. Data is processed descriptively.

\section{Results}

During the study period there were 162 deep neck abscess patients, 102 men $(62.96 \%)$ and 60 women $(37.04 \%)$. The ratio of men to women is $1: 1.7$ (table 1 ). The largest age group was 46-60 years as many as 55 patients $(33.95 \%)$.

Table 1. Sex type distribution

\begin{tabular}{ccc}
\hline Sex & Total & Percentage $(\boldsymbol{\%})$ \\
\hline Male & 102 & 62,96 \\
\hline Female & 60 & 37,04 \\
\hline Total & 162 & 100,00 \\
\hline
\end{tabular}

Table 2. Age distribution

\begin{tabular}{ccc}
\hline Age (year) & Total & Percentage (\%) \\
\hline $01-15$ & 7 & 4,23 \\
\hline $16-30$ & 32 & 19,75 \\
\hline $31-45$ & 49 & 30,25 \\
\hline $46-60$ & 55 & 33,94 \\
\hline$>60$ & 19 & 11,73 \\
\hline Total & 162 & 100,00 \\
\hline
\end{tabular}

Submandibular location was found in 69 patients $(42.59 \%)$, then submandibular \& parapharyngeal space in 28 patients $(17.28 \%)$. Most rarely in peritonsil \& parapharynx only in 1 patient $(0.63 \%)$. Deep neck abscess can occur in several locations at once (more than 1 potential cervical space), namely a combination of submandibular space, parapharynx, retropharynx, and peritonsil as many as 47 patients $(29.01 \%)$ table 3 .

Table 3. Deep neck abscess location

\begin{tabular}{lcc}
\hline Location & Total & Percentage (\%) \\
\hline Submandibular & 69 & 42,59 \\
\hline Peritonsillar & 26 & 16,05 \\
\hline Parapharyngeal & 14 & 8,64 \\
\hline Retropharyngeal & 4 & 2,47 \\
\hline Parotid & 2 & 1,23 \\
\hline $\begin{array}{l}\text { Submandibular \& } \\
\text { Parapharyngeal }\end{array}$ & 28 & 17,28 \\
\hline $\begin{array}{l}\text { Submandibular \& } \\
\text { Retropharyngeal }\end{array}$ & 4 & 2,47 \\
\hline $\begin{array}{l}\text { Peritonsillar \& } \\
\text { Parapharyngeal }\end{array}$ & 1 & 0,63 \\
\hline $\begin{array}{l}\text { Retroharyngeal \& } \\
\text { Parapharyngeal }\end{array}$ & 9 & 5,55 \\
\hline $\begin{array}{l}\text { Submandibular, } \\
\text { Retroharyngeal \& } \\
\text { Parapharyngeal }\end{array}$ & 5 & 3,09 \\
\hline Total & 162 & 100,00 \\
\hline
\end{tabular}

The most common causes were odontogenic infections as many as 85 patients $(52.47 \%), 24$ acute tonsil infections $(14.81 \%)$, diabetes mellitus in 14 patients (8.64\%). Other causes were Type 2 DM \& odontogenic in 27 patients $(16.67 \%)$, oropharyngeal infection in 11 patients $(6.79 \%)$ and DM with oropharyngeal infection in 1 patient $(0.62 \%)$. The factor of dental infection as the cause of deep neck abscess was found in 112 patients $(69.14 \%)$ table 4 .

Table 4. Etiology

\begin{tabular}{lcc}
\hline Etiology & Total & Percentage (\%) \\
\hline Odontogenic & 85 & 52,47 \\
\hline Acute tonsillitis & 24 & 14,81 \\
\hline Type 2 diabetes mellitus & 14 & 8,64 \\
\hline $\begin{array}{l}\text { Type 2 diabetes mellitus \& } \\
\text { odontogenic }\end{array}$ & 27 & 16,67 \\
\hline Oropharyngeal infection & 11 & 6,79 \\
\hline $\begin{array}{l}\text { Type 2 diabetes mellitus \& } \\
\text { Oropharyngeal infection }\end{array}$ & 1 & 0,62 \\
\hline Total & 162 & 100,00 \\
\hline
\end{tabular}

From the 138 patients (table 5), the highest growth of bacteria from pus culture were Klebsiella pneumonia (13.04\%), Streptococcus anginosus (10.88\%), Staphylococcus aureus $(8.70 \%)$, and also sterile (35.51\%).

The sensitivity test results for antibiotics from pus culture showed the highest sensitive number obtained by meropenem of $73.58 \%$, cefoperazone-sulbactam $69.36 \%$, and oxacillin $66.67 \%$. While the resistance of bacteria to ampicillin antibiotics (54.29\%), gentamycin (52.27\%), and ampicillin-sulbactam (37.89\%). 
Table 5. Culture from pus, blood and urine

\begin{tabular}{|c|c|c|c|c|c|c|}
\hline Bacteria & Pus & $\%$ & Blood & $\%$ & Urine & $\%$ \\
\hline Klebsiella pneumonia & 18 & 13,04 & 1 & 20,00 & - & - \\
\hline Streptococcus anginosus & 15 & 10,88 & - & - & - & - \\
\hline Staphylococcus aureus & 12 & 8,70 & - & - & - & - \\
\hline Streptococcus constellatus & 9 & 6,25 & - & - & - & - \\
\hline Acinobacter baumanii & 7 & 5,08 & 1 & 20,00 & 1 & 50,00 \\
\hline Streptococcus viridians & 4 & 2,90 & 2 & 40,00 & - & - \\
\hline Streptococcus acidominumus & 3 & 2,17 & - & - & - & - \\
\hline Staphylococcus hominis & 3 & 2,17 & - & - & - & - \\
\hline Staphylococcus haemolyticus & 3 & 2,17 & - & - & - & - \\
\hline Streptococcus agalactiae & 3 & 2,17 & - & - & - & - \\
\hline Streptococcus pyogenes & 3 & 2,17 & - & - & - & - \\
\hline Staphylococcus epidermidis & 2 & 1,45 & - & - & - & - \\
\hline Streptococcus oralis & 2 & 1,45 & - & - & - & - \\
\hline Streptococcus uberis & 2 & 1,45 & - & - & - & - \\
\hline Steril & 49 & 35,51 & - & - & - & - \\
\hline $\begin{array}{l}\text { ESBL (extended spectrum beta } \\
\text { lactamase) }\end{array}$ & 3 & 2,17 & - & - & - & - \\
\hline Total & 138 & 100,00 & 5 & 100,00 & 1 & 100,00 \\
\hline
\end{tabular}

Table 6. Sensitivity test results for antibiotics

\begin{tabular}{|c|c|c|c|c|}
\hline Antibiotic & $\sum$ & Sensitive & Intermediate & Resistant \\
\hline Ampicillin & 70 & $22(31,43 \%)$ & $10(14,28 \%)$ & $38(54,29 \%)$ \\
\hline Ampicillin-sulbactam & 48 & $28(47,46 \%)$ & $9(15,25 \%)$ & $32(37,89 \%)$ \\
\hline Penicillin G & 54 & $22(40,74 \%)$ & $1(1,85 \%)$ & $31(10,20 \%)$ \\
\hline Oxacillin & 36 & $24(66,67 \%)$ & 0 & $12(33,33 \%)$ \\
\hline Piperacillin tazobactam & 20 & $12(60,00 \%)$ & $2(10,00 \%)$ & $6(30,00 \%)$ \\
\hline Cefotaxime & 43 & $25(58,14 \%)$ & $5(11,63 \%)$ & $13(30,23 \%)$ \\
\hline Cefoperazone - sulbactam & 32 & $19(69,36 \%)$ & $3(9,38 \%)$ & $10(31,36 \%)$ \\
\hline Ceftriaxone & 37 & $19(51,35 \%)$ & $5(13,52 \%)$ & $13(35,13 \%)$ \\
\hline Ceftazidime & 40 & $23(57,50 \%)$ & $6(15,00)$ & $11(27,50 \%)$ \\
\hline Ciprofloxacin & 39 & $22(56,41 \%)$ & $3(7,69 \%)$ & $14(35,90 \%)$ \\
\hline Moxifloxacine & 20 & $13(65,00 \%)$ & $3(15,00 \%)$ & $4(20,00 \%)$ \\
\hline Levofloxacin & 65 & $41(63,07 \%)$ & $3(4,62 \%)$ & $21(32,31 \%)$ \\
\hline Cotrimoxazole & 83 & $47(56,65 \%)$ & $9(10,84 \%)$ & $27(32,53 \%)$ \\
\hline Tetracyclin & 39 & $16(41,03 \%)$ & $9(23,07 \%)$ & $14(35,90 \%)$ \\
\hline Erytromicin & 64 & $37(57,81 \%)$ & $3(4,69 \%)$ & $24(37,50 \%)$ \\
\hline Chloramphenicol & 83 & $51(61,45 \%)$ & $3(4,69 \%)$ & $20(24,10 \%)$ \\
\hline Gentamycin & 88 & $33(37,50 \%)$ & $9(10,23 \%)$ & $46(52,27 \%)$ \\
\hline Amikacin & 39 & $22(56,41 \%)$ & $1(2,56 \%)$ & $16(41,03 \%)$ \\
\hline Fosfomycin & 59 & $34(57,63 \%)$ & $9(3,77 \%)$ & $16(27,12 \%)$ \\
\hline Meropenem & 53 & $39(73,58 \%)$ & $2(3,77 \%)$ & $12(22,65 \%)$ \\
\hline Imipenem & 20 & $13(65,00 \%)$ & $3(15,00 \%)$ & $4(20,00 \%)$ \\
\hline
\end{tabular}


From 162 patients with deep neck abscess, the most common complications were sepsis with 48 patients $(29.63 \%)$, followed by upper airway obstruction, and tracheotomy with 10 patients $(6.17 \%)$.

Table 7. Complication

\begin{tabular}{lll}
\hline Complication & Total & $\begin{array}{l}\text { Percentage } \\
(\%)\end{array}$ \\
\hline Sepsis & 48 & 29,63 \\
Upper airway obstruction & 10 & 6,17 \\
Mediastinitis & 11 & 6,79 \\
Died & 13 & 8,02 \\
\hline
\end{tabular}

\section{Discussion}

From this study obtained that comparison of women and men is $1: 1.7$, similar to other studies that showed male prevalence of 1.5-1.7:1. This is probably due to men tend to neglect oral hygiene compared to women. ${ }^{3,5,6}$ Deep neck abscess was found at the age of 3 years to 82 years, with previous studies showing that the highest age range was 7-44 years and 20-39 years. The cause of deep neck abscess is mostly from dental infections $(52.47 \%)$, it is possible because at a young age most of patients ignore dental hygiene that lead to chronic dental infections that can causes abscess complications. ${ }^{5,6}$

In the neck region there are several potential spaces bounded by the cervical fasciae. Cervical fasciae are divided into two: superficial fasciae and deep fascia. Both of these fasciae are separated by thin platism muscle that extend anteriorly to the neck. The deep fascia surrounds the deep neck region consisting of 3 layers, the superficial layer, the medial layer, and the deep layer, which can be seen in Figures 1 and 2. The deep neck potential space is divided into space involving the area along the neck, suprahyoid space and infrahyoid space. The space involved in deep neck abscesses is along the neck consisting of retropharyngeal space, danger space, and prevertebral space. The suprahyoid space consists of the submandibular space, parapharyngeal space, parotid space, masticator space, peritonsil space, and temporal space. The infrahyoid space is the pretracheal space. ${ }^{7,8}$

The results of the study showed that the most common location is in the submandibular, found in 69 patients $(42,59 \%)$. The results of Motahari SJ et al. study said that submandibular abscess occurence is $45 \%$, $40.5 \%$ peritonsil abscess and $7.5 \%$ parapharyngeal abscess. In contrast to the results of Imanto's study, peritonsillar abscess was $32 \%$, submandibular abscess $18 \%$, combined abscess $25 \%$, and retropharyngeal abscess $14 \% .^{5,6}$

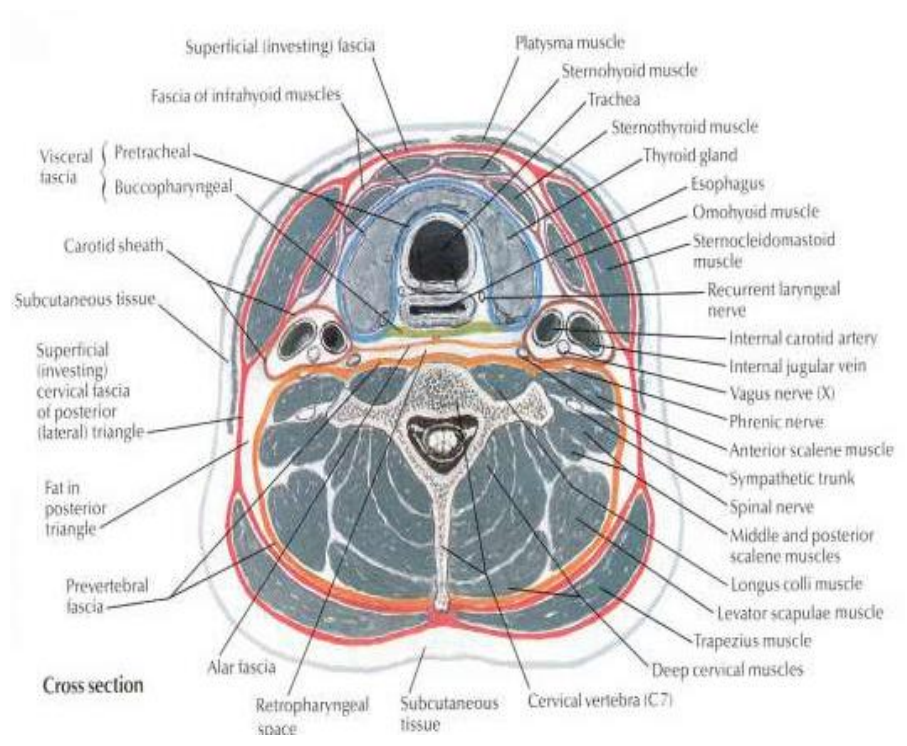

Figure 1. Cervical fascia. ${ }^{9}$

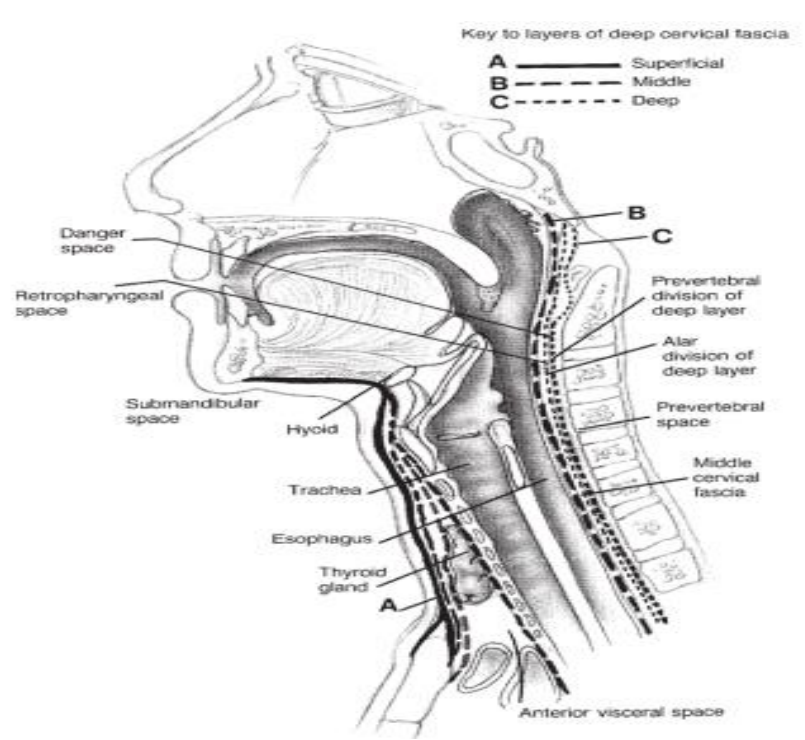

Figure 2. Sagittal section of neck ${ }^{9}$

The expansion mechanism of the abscess from the submandibular to the parapharyngeal and retropharyngeal space due to pressure (contraction) of the mouth floor muscles, as if pushing the pus into the parapharynx cavity and retropharynx (Figure 3). ${ }^{4}$ Combined abscesses consisting of two or three abscesses occur together, consisting of submandibular abscess, parapharynx, retropharynx, and peritonsil. The percentage of submandibular abscess expansion around this area is greater than the findings of other studies that 
reported only $25 \% .^{6}$ This peritonsillar abscess is a complication of acute tonsillitis. The pus located in the tonsillar magna crypts and can expand laterally in the peritonsil space. Piles of pus in the peritonsil space cause the tonsils to be pushed medioinferiorly. The spread of infection in the danger space area before the preantibiotic era caused mortality by $50 \%$, in the era of antibiotics the mortality rate decreased to $25 \%$., 9

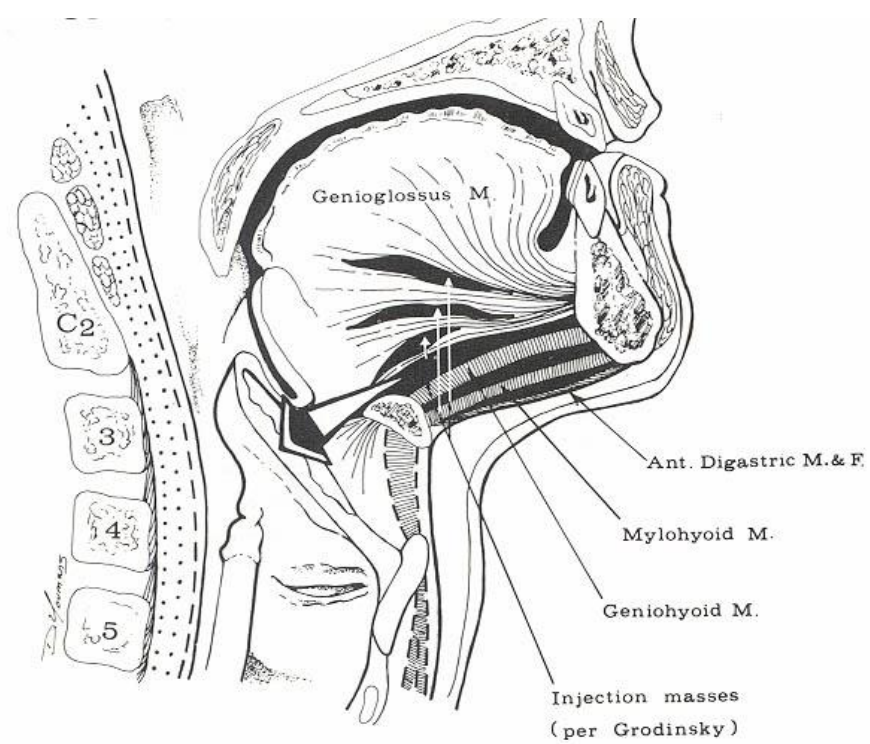

Figure 3. The mechanism of extending the pus into the parapharyngeal and retropharyngeal spaces. ${ }^{9}$

The most common source of infection in deep neck abscess came from odontogenic infections as many as 85 patients $(52.47 \%)$, DM 14 patients $(8.64 \%)$, while those caused by odontogenic, DM, and oropharyngeal infections were 42 patients (26.25\%). This result is in line with previous studies that odontogenic and respiratory infections are the most common etiology. Kim et al., Explained that tonsillectomy increases the risk of retropharyngeal abscess and parapharyngeal abscess in adulthood compared to children. ${ }^{9}$ This is because dental infections can affect the pulp and periodontal and then spread through the pulp or apical foramen to the surrounding area. Apical area of molar teeth above the mylohyoid muscle causes the spread of infection to enter the sublingual space first, while the second and third molars are under mylohyoid muscle so that the infection will be spread faster to the submandibular space. Grouping of causes of deep neck abscess infection can be seen in figure $4.6,10$

Inflammation or damage to chronic teeth problems (ex. dental caries and pulp gangrene) can cause submandibular abscess complications. The mandibular teeth are very close to the submandibular and sublingual spaces, which are functionally placed in one space, so that inflammation of the lower jaw can cause deep neck abscess complications, it is because the accumulation of pus in the submandibular space will then expand into the surrounding space. The risk of deep neck abscess after tonsillectomy in adolescents and adults is 1.43 times bigger compared to children. ${ }^{9}$

Most deep neck abscess is caused by a mixture of various bacteria (polymicrobials), both aerobes, anaerobes, and facultative anaerobic bacteria. The normal aerobic floras of oral cavity are Gram-positive aerobic cocci (Streptococcus sp.), anaerobes (Streptococcus sp., Peptococcus sp., Peptostreptococcus sp.); Gram negative aerobic cocci (Neisseria sp.), anaerob (Veillonella sp.); Gram positive aerobic bacilli (Diphtheroids), anaerobes (Clostridium sp., Actinomyces sp., Eubacterium sp., Lactobacillus sp.); and Gram negative aerobic bacilli (Haemophilus sp., Eikenella sp.), anaerob (Prevotella/Bacteroides sp., Fusobacterium sp., Porphyromonas sp.). In dental infections, anaerobic bacteria are more numerous than aerobic and facultative anaerobes. Bacteria growth results in this study were Klebsiella pneumonia (13.04\%), Streptococcus anginosus (10.88\%), Staphylococcus aureus (8.70\%), Streptococcus constellatus (6.25), and also sterile (35.51\%). In contrast to the results of Novii's study which received $\alpha$-Haemolytic Streptocccus (37\%), Klebsiella sp. (25\%), Enterobacter sp. (19\%) and Staphylococcus aureus $(12.5 \%) .{ }^{8,11}$

The abscess culture is divided into three groups. The first group, bacteria from the oral cavity associated with odontogenic disorders, including Fusobacterium sp. and Prevotella sp. The second group, bacteria from the oral cavity that were not associated with odontogenic disorders were Bacteroides sp., Staphylococcus aureus, Klebsiella sp., Streptococcus sp., and Candida albicans. The third group, bacteria that do not come from the oral cavity include Streptococcus pneumoniae, Citrobacter sp., and Salmonella enteriditis. A high percentage of third group culture (34.22\%), species of bacteria are not specific, only show aerobic or anaerobic bacteria, and also types of Gram positive or negative., ${ }^{3,11,12}$

The Staphylococcus genus that has clinical importance are Staphylococcus aureus, Staphylococcus epidermidis, and Staphylococcus saprophyticus. Staphylococcus aureus, which are the main pathogens in humans, are coagulase-positive, localized, quickly form supuration, but recover quickly when pus drainage is performed. Streptococcus sp. that often plays a role in deep neck abscess is Streptococcus viridans, $\alpha$ Haemolytic Streptococcus, $\quad \beta$-Haemolyticus Streptococcus, and Streptococcus pneumonia. ${ }^{11,13}$

Pus culture is done to determine the type of bacteria and their sensitivity to antibiotics. In this study all patients underwent abscess drainage and received empirical antibiotics, namely a combination of 


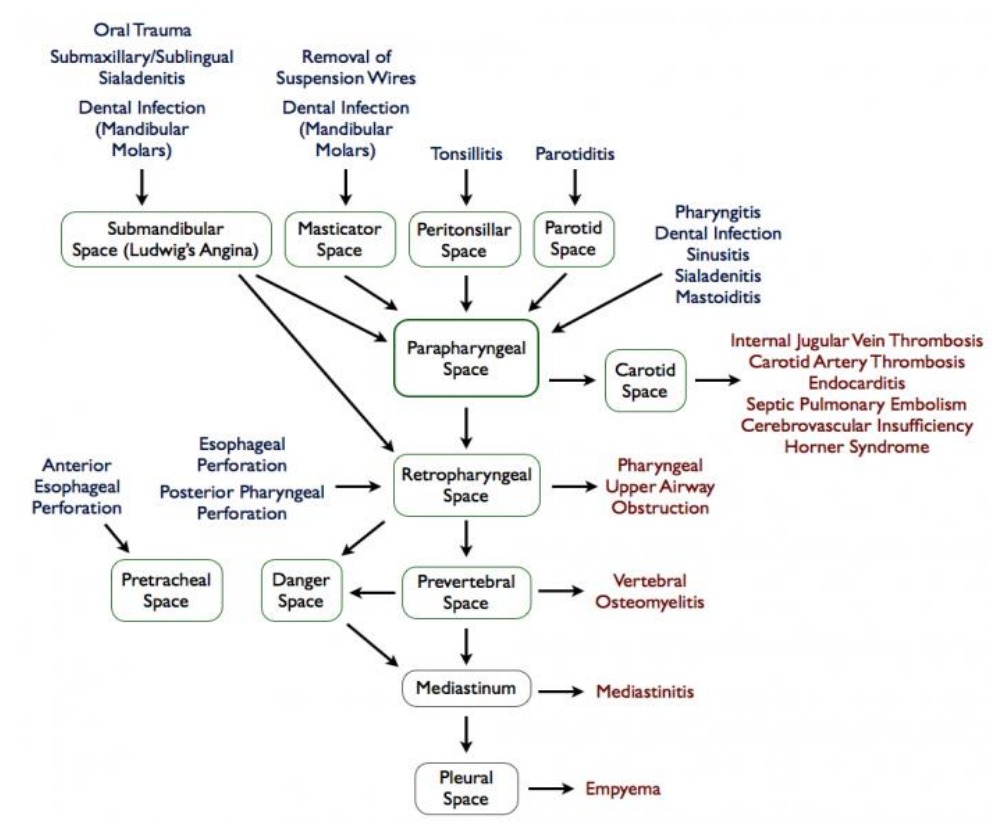

Figure 4. Pathway that connects the causes and the spread of deep neck infections.

cefriaxone and metronidazole. The highest sensitivity test results were meropenem $(73.58 \%)$, cefoperazonesulbactam $(69.36 \%)$, oxacillin $(66.67 \%)$. While the

The results of Boyanova et al's research showed that resistance to amoxicillin was $26.7 \%$. While clindamycin and metronidazole against gram negative anaerobes were $5.4 \%$ and $2.5 \%$ respectively. Against gram positive $4.5 \%$ and $58.3 \%$ respectively. Thus, metronidazole and clindamycin are the main choices for killing anaerobic bacteria. Various empirical combinations of antibiotics are recommended based on the results of sensitivity test using ceftriaxone and clindamycin, cefuroxime and metronidazole, penicillin and gentamycin, and flucloxacine and metronidazole. ${ }^{5,13}$

Various research reported indicate that the best combination of antibiotics is a combination of ceftriaxone-clindamycin, while gentamycin shows a synergistic effect with penicillin. Clindamycin is effective against Streptococcus sp., Pneumococcus sp., and Staphylococcus sp. which are resistant to penicillin. Administration of clindamycin is highly recommended in polymicrobial infections including Bacteroides sp. and other anaerobic bacteria in the oral area. When anaerobic bacteria are obtained, metronidazole, clindamycin, carbapenem or combination of penicillin and $\beta$-lactam inhibitors will be chosen. Metronidazole is also effective as amebicide, whereas ceftriaxone and cefotaxime have effectiveness against Streptococcus sp. Ceftriaxone is very effective against gram negative and Haemophillus sp. Antibiotics can be continued if empiric antibiotic shows improvement in the clinical condition. ${ }^{5,13}$ resistance to ampicillin antibiotics $(54.29 \%)$, gentamycin (52.27\%), ampicillin-sulbactam (37.89\%). ${ }^{5,13}$

Table 8. First line antibiotic for deep neck abscess ${ }^{8}$

\begin{tabular}{|c|c|}
\hline $\begin{array}{lr}\text { Community } & \text { Acquired } \\
\text { Infection } & \text { (Gram } \\
\text { positive, } & \text { Gram } \\
\text { negative, anaerobes) }\end{array}$ & $\begin{array}{l}\text { - Ampicillin-sulbactam } 1.5 \\
\text { to } 3 \text { g. IV every } 6 \text { hours } \\
\text { - Clindamycin (if allergic to } \\
\text { penicillin) 600-900 mg IV } \\
\text { every } 8 \text { hours }\end{array}$ \\
\hline $\begin{array}{l}\text { Pseudomonas \& Gram } \\
\text { negative }\end{array}$ & $\begin{array}{l}\text { - Ticarcillin clavulanate } 3 \mathrm{~g} \\
\text { IV every } 6 \text { hours } \\
\text { - Piperacillin tazobactam } 3 \mathrm{~g} \\
\text { IV every } 6 \text { hours } \\
\text { - Imipenem cilastatin } 500 \\
\text { mg IV every } 6 \text { hours } \\
\text { - Ciprofloxacin (if allergic to } \\
\text { penicillin) } 400 \mathrm{mg} \text { IV every } \\
12 \text { hours } \\
\text { - Levofloxacin (if allergic to } \\
\text { penicillin) } 750 \mathrm{mg} \text { IV every } \\
24 \mathrm{hr}\end{array}$ \\
\hline $\begin{array}{l}\text { Methicillin Resistant } \\
\text { Staphylococcus } \\
\text { aureus/MRSA }\end{array}$ & 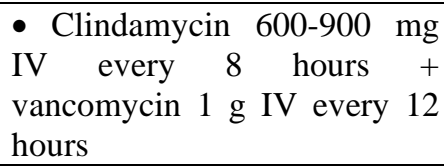 \\
\hline $\begin{array}{l}\text { Necrotizing Fasciitis } \\
\text { (mixed of Gram Positif } \\
\text { dan Anaerobes) }\end{array}$ & $\begin{array}{l}\text { - Ceftriaxone } 2 \text { g IV every } 8 \\
\text { hours + clindamycin } 600-900 \\
\text { mg IV every } 8 \text { hours + } \\
\text { metronidazole } 500 \text { mg IV } \\
\text { every } 6 \text { hours }\end{array}$ \\
\hline
\end{tabular}


Evacuation of abscesses on deep neck abscess treatment aims to remove pus properly and prevent complications. Infection can extend to other deep neck spaces so that it can cause complications including airway obstruction, pneumonia, necrotizing fasciitis, mediastinitis due to inferior abscess propagation, vascular complications (Lemierre's syndrome and carotid artery rupture), sepsis, osteomyelitis, neurological deficits and fistulas due rupture of an abscess. In this study, the most common complications were sepsis (29.63\%), upper airway obstruction to tracheotomy $(6.17 \%)$, mediastinitis $(6.79 \%)$, and death $(8.02 \%))^{14,15}$

People with deep neck abscess plus sepsis are generally accompanied by comorbid such as Diabetes Mellitus (DM). In patients with DM there is a decrease in the function of the immune response which results in more susceptible to various types of infections. Diabetes patients commonly have angiopathy, decreased endothelial function, and impaired vital organ function. Management of deep neck abscess in people with DM must be done carefully, because invasive measures without controlling blood sugar can aggravate the infection, resulting in sepsis and death. ${ }^{14,15}$

\section{Conclusion}

The most common location of deep neck abscess in the submandibular area with sepsis as complication. The most common etiology is dental and tonsils infection from Klebsiella pneumonia, Staphylococcus aureus, and Streptococcus anginosus. The regiment therapy of meropenem, cefoperazone-sulbactam, and oxacillin are still the most sensitive antibiotic.

\section{Conflict of Interest}

The author stated there is no conflict of interest.

\section{References}

1. Johnson J, Rosen C, Newlands S and Amin M. Deep Neck Infections. in: Aynehchi B, (Ed.). Bailey's Head and Neck Surgery-Otolaryngology. Philadelphia: Lippincot Williams \& Wilkins, 2014, P. 794-813.

2. Dhingra P. Neck Spaces and Fasciael Planes. Disease Of Ear, Nose and Throat. India: Elsevier India, 2017, P. 55774.

3. Pardal-Peláez B, Pardal-Refoyo JL, Ochoa-Sangrador C, González-Serrano J, Montero-Martín J and López-Quiles J. Analysis of The Prevalence of Dental Origin of Deep Neck Infections. Journal of Oral and Maxillofacial Surgery, Medicine, and Pathology. 2018; 30: 180-6.

4. Snow J and Wackym P. Deep Head and Neck Space Infections. in: Yellen R, (Ed.). Ballenger's Otorhinolaryngology Head and Neck Surgery. Lewiston: BC Decker Inc, 2009, P. 783-8.

5. Motahari SJ, Poormoosa R, Nikkhah M, Bahari M, Shirazy SM and Khavarinejad F. Treatment and Prognosis of Deep Neck Infections. Indian Journal of Otolaryngology and Head and Neck Surgery : Official Publication of The Association of Otolaryngologists of India. 2015; 67: 134-7.

6. Imanto M. Evaluasi Penatalaksanaan Abses Leher Dalam di Departemen THT-KL Rumah Sakit Hasan Sadikin Bandung Periode Januari 2012-Desember 2012. Jurnal Kedokteran Universitas Lampung. 2015; 5: 33-7.

7. Fagan J And Morkel J. Surgical Drainage Of Neck Abscesses: (208, Accessed May 29th, 2018).

8. Flint P, Haughey B, Lund V and Niparko J. Deep Neck Space Infections. in: Oliver E And Gillespie M, (Eds.). Cummings Otolaryngology Head \& Neck Surgery. Philadelphia: Mosby Elsevier, 2010, P. 201-8.

9. Kim SY, Min C, Lee WH And Choi HG. Tonsillectomy Increases The Risk of Retropharyngeal and Parapharyngeal Abscesses in Adults, But Not In Children: A National Cohort Study. Plos One. 2018; 13: E0193913.

10. Huang TT, Liu TC, Chen PR, Tseng FY, Yeh TH And Chen YS. Deep Neck Infection: Analysis Of 185 Cases. Head \& Neck. 2004; 26: 854-60.

11. Jawetz. Classification of Bacteria. In: Brooks G, Butel J, Morse S, Carrol K and Mietzner T, (Eds.). Medical Microbiology. New York: Mc Graw Hill, 2013, P. 43-54.

12. Lee K, Chan $Y$ and Das S. Neck Spaces and Fasciael Planes. In: Gillespie B, (Ed.). Essential Otolaryngology Head And Neck Surgery. USA: Mc Graw Hill Medical, 2012, P. 557-64.

13. Boyanova L, Kolarov R, Gergova G, Et Al. Anaerobic Bacteria In 118 Patients With Deep-Space Head and Neck Infections From The University Hospital of Maxillofacial Surgery, Sofia, Bulgaria. Journal Of Medical Microbiology. 2006; 55: 1285-9.

14. Gleeson M, Browning G, Burha M, Clarke R, Hibbert J and Jones N. Benign Neck Disase: Infections and Swellings. In: Clarke P, (Ed.). Scott-Brown's Otorhinolaryngology Head \& Neck Surgery. London: Edward Arnold Ltd, 2008, P. 1777-88.

15. Bigcas J-LM And Jain KS. Management of Parapharyngeal and Retropharyngeal Space Infections. Operative Techniques In Otolaryngology-Head And Neck Surgery. 2017; 28: 229-37. 